BIBLIOTIKA : Jurnal Kajian Perpustakaan dan Informasi

Volume 3 Nomor 1, 2019

Journal homepage $:$ http://journal2.um.ac.id/index.php/bibliotika

\title{
PERILAKU INFORMASI REMAJA DALAM MEMANFAATKAN FACEBOOK
}

\author{
Amalia Nurma Dewi, Zeni Istiqomah ${ }^{*}$ \\ Program Studi Ilmu Perpustakaan, Fakultas Sastra, Universitas Negeri Malang
}

\begin{tabular}{|c|c|}
\hline $\begin{array}{l}\text { A R T I L E } \\
\text { I N F O }\end{array}$ & A B S T R A C T \\
\hline $\begin{array}{l}\text { Article history: } \\
\text { Received: 2 Jan } 2019 \\
\text { Accepted: } 20 \text { Apr } 209 \\
\text { Published: } 31 \text { May } 2019 \\
\text { Keyword: } \\
\text { Perilaku informasi, } \\
\text { facebook, remaja }\end{array}$ & $\begin{array}{l}\text { Penelitian perilaku informasi remaja dalam memanfaatkan media } \\
\text { sosial facebook dilakukan karena pemanfaatan media sosial sebagai } \\
\text { sumber informasi semakin marak dikalangan remaja. Penelitian } \\
\text { diawali dengan menganalisis kebutuhan informasi samapai } \\
\text { pemanfaatan informasi. Pada analisis kebutuhan informasi } \\
\text { ditemukan bahwa motivasi utama informan yang menyebabkan } \\
\text { munculnya kebutuhan informasi adalah motivasi sosial dan rasa } \\
\text { ingin tahu terhadap hal baru. Motivasi tersebut berubah menjadi } \\
\text { kebutuhan informasi yang berkaitan dengan informasi tentang } \\
\text { lingkungan sosial dan juga hiburan. Faktor pendorong utama yang } \\
\text { menyebabkan informan merubah kebutuhan informasinya } \\
\text { menjadi perilaku informasi adalah karena informan membutuhkan } \\
\text { informasi dari media sosial untuk menunjukkan identitas diri, } \\
\text { membangun citra, terhubung, dan menjadi bagian dari suatu } \\
\text { kelompok. Saat kebutuhan informasi tersebut tidak dipenuhi } \\
\text { remaja merasakan anxiety yang dikarenakan perasaan kesepian, } \\
\text { merasa tidak dianggap keberadaannya, dan tersisihkan dari } \\
\text { lingkungan sosial. Pencarian informasi menunjukkan pencarian } \\
\text { informasi pasif, hal tersebut dikarenakan karakteristik dari facebook } \\
\text { yang menerapkan konsep web 3.0, selain itu karakteristik lain } \\
\text { berupa terbatasnya kata kunci yang bisa digunakan untuk } \\
\text { pencarian informasi. di dalam facebook pencarian informasi hanya } \\
\text { bisa dilakukan dengan cara mencari nama pengguna, faktor } \\
\text { tersebut menyebabkan pencarian informasi sebagian besar } \\
\text { informan menunjukkan perilaku pencarian pasif. Perilaku } \\
\text { pemanfaatan informasi menunjukkan bahwa sebagian besar } \\
\text { informasi yang mereka dapatkan tidak digunakan, faktor } \\
\text { penyebabnya dikarenakan informan melakukan aktifitas kognitif } \\
\text { berupa menganalisis informasi yang didapatkannya dari segi author } \\
\text { informasi, konten informasi, serta keterbaruan. Mereka } \\
\text { menghindari menggunakan informasi yang kurang berkualitas } \\
\text { karena khawatir terhadap pendapat anggota lain dalam kelompok }\end{array}$ \\
\hline
\end{tabular}

\footnotetext{
${ }^{*}$ Corresponding author.

E-mail addresses: amalia.nurma.fs@um.ac.id (Amalia Nurma Dewi), zeni.istiqomah@gmail.com (Zeni Istiqomah)
}

ISSN : 2579-3802 (Online) - BIBLIOTIKA : Jurnal Kajian Perpustakaan dan Informasi is licensed under Creative Commons Attribution-ShareAlike 4.0 International License (http://creativecommons.org/licenses/BY/4.0/). 
Masuknya era informasi membawa perubahan yang signifikan terhadap perilaku informasi. Perilaku Informasi didefinisikan sebagai keseluruhan perilaku yang ditunjukkan oleh seseorang atau sekelompok orang saat berinteraksi dengan informasi, mulai dari perumusan kebutuhan informasi, pencarian, pemanfaatan, evaluasi, dan presentasi. Perubahan perilaku informasi di era informasi terutama berkaitan dengan meningkatnya kompleksitas kebutuhan informasi dan sarana yang dimanfaatkan untuk memenuhi kebutuhan tersebut (Almas, Andajani, \& Istiqomah, 2018; Nahrowi, 2017; Noor, 2018).

Kompleksitas kebutuhan informasi berkaitan dengan jenis informasi yang dibutuhkan. Sebelum era informasi, kebutuhan informasi cenderung berkaitan dengan kebutuhan informasi fisiologis yang digunakan untuk memenuhi kebutuhan dasar, seperti makan, minum, dan tempat tinggal. Masuknya era informasi membuat kebutuhan tersebut berkembang menjadikebutuhan kognitif, afektif, integrasi personal dan integrasi sosial.

Kebutuhan kognitif berkaitan erat dengan kebutuhan untuk menambah informasi, pengetahuan, dan pemahaman seseorang akan lingkungannya. Kebutuhan afektif berkaitan dengan penguatan estesis, hal yang dapat menyenangkan dan pengalaman-pengalaman emosional, kebutuhan integrasi personal berkaitan dengan penguatan kredibilitas, kepercayaan, dan status individu, dan yang terakhir adalah kebutuhan integrasi sosial yang berkaitandengan penguatan hubungan dengan keluarga, teman, dan orang lain di dunia (Katz, Gurevitch, dan Haas dalam Yusuf, 2010).

Perubahan kompleksitas kebutuhan informasi juga menyebabkan perubahan pada sarana pemenuhan kebutuhan informasi. Sarana pemenuhan kebutuhan informasi saat ini berkembang ke arah digital yaitu internet, karena dinilai lebih bisa mendukung peningkatan kuantitas dan kualitas informasi yang berkaitan dengan produktivitas, penyebaran, dan pemanfaatan informasi. Berdasarkan hasil penelitian yang dilakukan oleh Asosiasi Penyelenggara Jasa Internet Indonesia (APJII) pada tahun 2017 sebanyak 53\% juta jiwa memanfaatkan internet untuk memenuhi kebutuhan informasi. Lebih lanjut lagi, angka pemanfaatan internet terbesar ada pada pemanfaatan sosial media yang mencapai angka 97\%. Media sosial yang paling banyak dimanfaatkan adalah facebook, dengan presentase mencapai 85\%. Secara tidak langsung, presentase tersebut menunjukkan bahwa sebagian besar masyarakat indonesia memenuhi kebutuhan informasinya dengan memanfaatkan facebook.

Pemenuhan kebutuhan informasi menggunakan facebook merupakan suatu fenomena yang unik untuk dikaji. Seperti yang kita tahu bahwa facebook merupakan Social Network Site (SNS) yang memiliki karakteristik informasi yang bias, realibilitas rendah, dan kurang komperhensif sementara konten informasinya cenderung berisi tentang hiburan, informasi terbaru berkaitan dengan komunitas, maupun informasi personal berkaitan dengan kehidupan seseorang (Caers, 2013). Karakteristik informasi yang demikian akan sangat mempengaruhi informasi yang didapatkan. Pada era dimana informasi memiliki kekuatan untuk untuk mempengaruhi kualitas kehidupan sesorang, maka penelitian ini penting untuk dilakukan.

Berdasarkan latar belakang yang di atas, masalah yang menjadi fokus dalam artikel ini adalah, bagaimanakah perilaku informasi remaja dalam memanfaatkan media sosial?

Batasan masalah dalam penelitian ini adalah perilaku informasi remaja yang memahami konsep perilaku informasi, berada di Kota Malang, dengan usia antara 18 sampai 24 sebagai pengguna media sosial facebook secara aktif. Facebook dipilih karena sebagian besar masyarakat Indonesia terutama dikalangan remaja memanfaatkan sosial media ini. 


\section{LANDASAN TEORI}

Berisikan landasan teori yang mencakup kebutuhan informasi, perilaku informasi, facebook, dan penelitian terkait

\section{Kebutuhan Informasi}

Setiap individu atau kelompok masyarakat memiliki kebutuhan informasi yang beragam dalam menyelesaikan permasalahan hidupnya. Terlebih bagi masyarakat informasi yang memiliki intensitas yang tinggi dalam memanfaatkan informasi. Tingkatan kebutuhan informasi antara individu satu dengan yang lain. Kebutuhan informasi individu jika dikaitkan dengan lingkungkunganya terbagi menjadi 4 kategori. Menurut Katz, Gurevitch, dan Hass dalam Yusuf (2010), mengemukakan bahwa ada beberapa kebutuhan informasi individu terkait dengan konsisi lingkungannya yaitu: (a) kebutuhan kognitif yaitu kebutuhan ini terkait dengan pemenuhan kebutuhan informasi yang meliputi pemahaman, pengetahuan, dan penerapan informasi. (b) Kebutuhan afektif berkaitan dengan penguatan estetis dengan untuk memberikan pengalaman emosional. Beberapa orang berpendapat kebutuhan ini berhubungan dengan hiburan dan kesenangan. Berbagai media dan kegiatan dapat dilakukan untuk memenuhi kebutuhan afektif. (c) Kebutuhan integrasi personal ini yaitu terkait dengan aktualisasi diri masing-masing individu. Setiap individu memiliki kebutuhan informasi terkait dengan peningkatan status, kepercayaan, dan penguatan kredibilitas. (d) Kebutuhan integrasi sosial, ini berhubungan dengan penguatan kebutuhan untuk interaksi individu terhadap keluarga, masyarakat, dan lingkungan. Kebutuhan integrasi sosial di dasari oleh keinginan individu untk bergabung dengan suatu kelompok atau masyarakat. Ketika individu atau kelompok mencari informasi maka dapat dikelompokkan untuk memenuhi kebutuhan apa saja informasi yang telah diperoleh tersebut.

Kebutuhan informasi pada dasarnya timbul dari adanya kesenjangan. Kesenjangan antara apa yang seharusnya dengan kenyataan yang ada, dalam konteks ini kesenjangan yang terjadi adalah kesenjangan antara dirinya sendiri dengan pengetahuan yang dimiliki. Kebutuhan informasi tidak muncul secara tiba-tiba tanpa adanya pengaruh dari berbagai pihak. Kebutuhan informasi seseorang dipengaruhi oleh banyak faktor, termasuk konsisi yang ada disekitar individu tersebut.

Menurut Wilson (1999), kebutuhan informasi seseorang tidak dapat berdiri sendiri, namun dipengaruhi beberapa faktor yaitu faktor dari individu, peran sosial dan lingkungan.

$$
\text { Context of information need }
$$

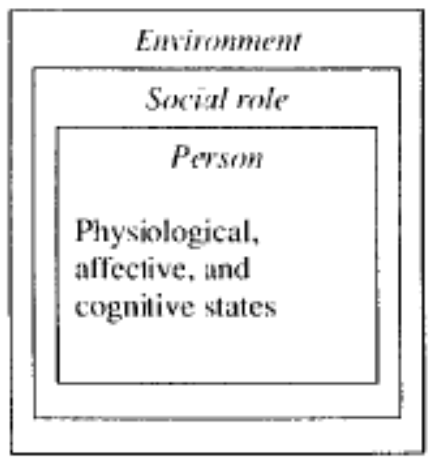

Berdasarkan penjelasan Wilson (1999) kebutuhan informasi seseorang dipengaruhi oleh kondisi dari seseorang tersebut, baik yang terkait kondisi individu maupun hubungan dengan lingkungan maupun sosial. Kondisi individu sangat berpengaruh pada kebutuhan informasi seseorang. Kondisi individu yang mempengaruhi kebutuhan informasi seseorang yaitu terkait dengan fisiologi, afektif, dan kognitif. Kebutuhan fisiologi berhubungan dengan pemenuhan kebutuhan terhadapkondisiseseorang. Misalnya makan, tempat tinggal, pakaian, seksual (Yusuf, 2010). Kebutuhan fisiologi berbengaruh terhadap kebutuhan informasi seseorang. Afektif berkaitan dengan kebutuhan emosional seseorang, yaitu terkait dengan pengatan estetika dan hiburan. Kognitif berkaitan dengan bagaimana individu memperoleh informasi dan pengetahuan untuk memahami lingkungan dan memecahkan persoalan yang ada. Selain itu kebutuhan 
informasi juga dipengaruhi oleh social role dari masing-masing individu. Peran individu dalam kegiatan atau pekerjaan dan juga tingkatan bekerja seseorang akan berpengaruh pada pemenuhan kebutuhan informasi seseorang (Wilson, 2000). Yang ketiga dipengaruhi oleh faktor lingkungan. Kondisi lingkungan sekitar yang ada yaitu lingkungan kerja, sosial, politik, ekonomi, budaya, dan fisik (Wilson, 2000).

\section{Perilaku Informasi}

Perilaku informasi adalah keseluruhan tingkah laku atau pola laku manusia terkait dengan keterlibatan informasi (Yusuf, 2010). Wilson (2000) menjelaskan bahwa Information Behavioris the totality of human behavior in relation to sources and channels of information, including both active and passive information seeking, and information use. Hal ini dapat dimaknai bahwa perilaku informasi merupakan keseluruhan tingkah laku individu terkait dengan sumber dan saluran informasi yang digunakan, termasuk tentang pencarian atau penelusuran informasi dan pemanfaatan informasi tersebut. Salah satu model yang digunakan untuk mengetahui perilaku informasi seseorang dikenal dengan sebutan Wilson 1996 Model of Information Behaviour (Wilson, 2000). Model ini dicetuskan oleh TD. Wilson yang digambarkan sebagai berikut:

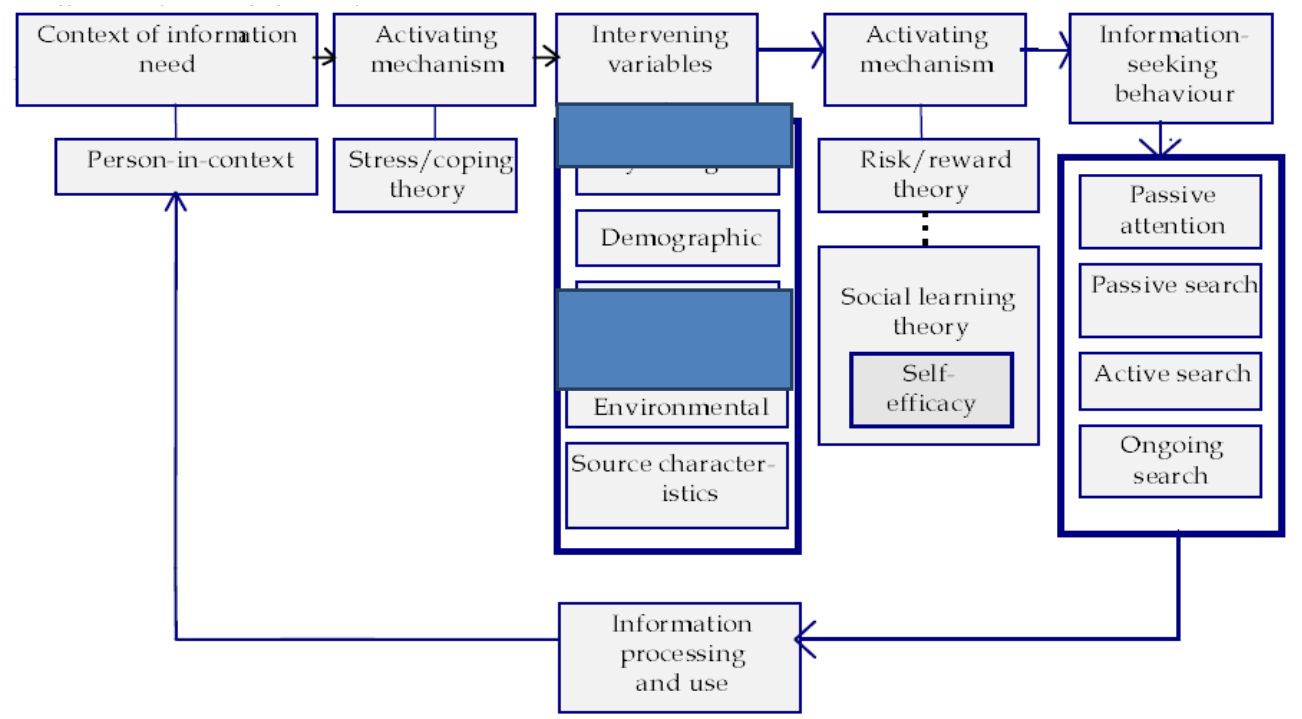

Model perilaku informasi yang digambarkan oleh Wilson digambarkan dalam sebuah siklus yang didalamnyasaling berkaitan antara satu aspek dengan aspek yang lain. Perilaku informasi seseorang pertama kali dipicu oleh adanya kebutuhan informasi. Seseorang yang memiliki kebutuhan informasi ini tidak secara langsung menjadi perilaku informasi, namun dipengaruhi oleh pemahaman seseorang tentang tekanan dan persoalan hidup yang dialami (Pendit, 2008). Kebutuhan informasi muncul karena adanya kesenjangan antara individu dengan informasi yang dimiliki. Ketika terjadi kesenjangan maka munculah aktivitas untuk membutuhkan informasi.

Aktivitas memenuhi kebutuhan informasi ini disebut sebagai perilaku informasi. Perilaku informasi pada dasarnya tidak berdiri sendiri. Menurut Wilson (1999), perilaku informasi individu dipengaruhi oleh

a. Demographic (demografis)

Kondisi demografis seseorang berkaitan dengan data kependudukan. Kondisi demografis seseorang meliputi jenis kelamin, usia, pendidikan, asal, lokasi/wilayah tempat tinggal, kebangsaan, dan lain-lain. Seseorang yang memiliki pendidikan sarjana tentunya memiliki perilaku yang berbeda dengan lulusan SMA. Begitu juga terkait dengan lokasi tempat tinggal. Jika sseseorang tinggal di daerah pegunungan yang jauh dari jangkauan internet, tentunya orang tersebut hanya mengandalkan sumber informasi tertentu (buku, majalah, surat kabarr, televisi) dalam perilaku informasinya. Berbeda dengan seseorang yang tinggal didaerah kota 
atau daerah yang terjangkau dengan internet, tentu perilaku informasi yang berbeda dalam pemenuhan kebutuhan informasinya.

b. Role-related or interpersonal (peran seseorang dimasyarakat)

Peran seseorang di masyarakat akan berpengaruh pada perilaku informasi orang tersebut. Peran seseorang juga akan berdampak pada hubungan personal dan interpersonal di dalam masyarakat. Misalnya seorang ketua RT tentunya memiliki perilaku informasi yang lebih kompleks, jika dibandingkan dengan mayarakat biasa. Ketua RT membutuhkan informasi yang lebih luas, sehingga berpengaruh pada perilaku informasi yang dilakukan. Seorang Pustakawan dan pelajar juga memiliki perilaku informasi yang berbeda dalam memenuhi kebutuhan informasinya. Jika pustakawan berhadapan dengan sumber informasi yang lebih kompleks dan tahu bagaimana menelusur dan menemukan informasinya dengan tepat, seorang pelajar belum tentu mampu melakukannya karena keterbatasan kemampuan dan pengetahuan.

c. Environment (lingkungan)

Kondisi yang ada disekitar individu secara langsung maupun tidak langsung berpengaruh terhadap perilaku informasi seseorang. Lingkungan dalam hal ini luas, bisa dimaknai sebagai lingkungan kerja, sosio-cultur, ekonomi, dan politik (Wilson, 2000).

Selain lima faktor di atas, dalam perilaku informasi juga dipengaruhi oleh faktor resiko dan imbalan yang diperoleh dalam penelsuran informasi. Pada tahapan ini, seseorang akan berfikir panjang dalam melakukan sesuatu, terutama berkaitan dengan pencarian dan penemuan informasi yang dilakukan. Hal ini tentunya disesuaikan dengan kondisi yang ada dari masingmasing Individu. Pendit (2008) memberikan contoh terkait hal ini, misalnya seorang ilmuwan terkenal merasa akan terlihat bodoh di hadapan pustakawan. Hal inisedikit berbeda jika dibandingkan dengan dosen yang tidak mempedulikan citranya di depan pustakawan. Ilmuwan mungkin merasa gengsi ketika bertanya kepada pustakawan, tapi mungkin dosen tidak pedulu karena memperoleh imbalan atau keuntungan yang sesuai dari bertanya kepada pustakawan.

Tahap akhir dalam model ini yaitu kegiatan dan reaksi yang dilakukan oleh seeorang dalam mencari dan menemukan informasi. Perilaku seseorang dalam mencari informasi tentunya beragam. Ada yang bertindak dengan perhatian pasif misalnya dengan melihat-lihat atau observasi sederhana. Selain itu adapula yang bertindak sebagai pencari pasif yaitu dengan cara bertanya kepada teman atau browsing secara serampangan. Ada yang melakukan pencarian aktif dengan searching sesaai dengan yang diinginkan, membandingkan informasi yang diperolehnya. Ada pula yang sampai pada tahap pencarian lanjutan, misalnya dengan menggunakan Advance search, bolean operator, dan lain-lain. Setiap individu tentunya memiliki cara yang berbeda dalam pencarian informasi.

\section{Facebook}

Salah satu media sosial yang sangat populer dikalangan masyarakat adalah facebook. Media sosial ini mulai meminpin pasar sejak April 2008, dengan berbagai fitur dan iklan yang ada di dalamnya (Treadaway \& Smith, 2010). Facebook juga sebagai media sosial yang sangat kompleks sehingga masih digemari oleh masyarakat hingga saat ini. Di Indonesia sendiri, angka pemanfaatan facebook sangat tinggi yaitu mencapai $85 \%$ dari total pengguna internet yang ada di Indonesia. Meskipun banyak media sosial lain yang mulai bermunculan, namun facebook masih sering dimanfaatkan oleh masyarakat.

Facebook adalahsebauh aplikasi yang dijalankan di atas platform facebook dan memungkinkaan pengembang program berinteraksi dengan pengguna (Hermina, 2010). Facebook sebagai website jaringan sosial yang mana para pengguna dapat bergabung dalam komunitas tertentu untuk berinteraksi dengan orang lain, dapat menambahkan teman, chating atau berkirim pesan secara personal, dan dapat merubah tampilan profil (Saputra, 2010). Seseorang dapat mengakses facebook dengan membuka situs web facebook.com. Jika seseorang belum memiliki akun, maka dapat membuat akun terlebih dahulu dengan memasukkan identitas 
diri. Setelah itu pengguna dapat melengkapi gambar profil dan juga foto sampul. Halaman profil dianggap sebagai dinding sendiri sedangkan beranda merupakan halaman luar yang berisi informasi dan postingan-postingan dari pengguna lain. Pengguna facebook dapat memposting status yang diinginkan, dapat menyukai dan menanggapi status dan informasi yang disampaikan pengguna lain. selain itu pengguna juga dapat bergabung dalam komunitas yang diinginkan, mencari teman baru dan juga berkirim pesan dengan pengguna lain (Cares et.al, 2013).

Facebook sebagai sebuah aplikasi dua arah, yaitu dapat melihat dan dilihat atau disebut prosume yang dapat memproduksi dan mengkonsumsi pada waktu yang bersamaan (Stroud et al. dalam Cares et al., 2013). Pengguna facebook dapat melihat status dari pengguna lain, begitu sebaliknya status kita dapat dilihat dan dibaca oleh pengguna lain. Facebook sebagai Social Network Site (SNS) sebagai wadah untuk berkomunikasi dengan orang lain yang tergabung di dalamnya. Facebook juga dijadikan ajang untuk mempromosikan diri (narsis) dan mempromosikan hal lain seperti berjualan online. Banyak orang memanfaatkan facebook untuk berjualan, untuk berdakwah, dan penyebaran informasi lain. Cares et.al (2013), menyatakan bahwa penggunaan informasi yang terdapat dalam facebook dapat digunakan untuk memberikan pengaruh pada penggunanya, seperti ajang untuk narsis dan ajang untuk menghibur diri. Selain itu adanya facebook dapat menjembatani komunikasi antara individu satu dengan individu yang lain baik melalui pesan pribadi (chatting), posting di dinding (status), komentar, dan lain-lain.

Informasi yang tersedia difacebook sangat beragam, hal ini tergantung dengan siapa seseorang itu berteman dan mengikuti komunitas yang ada. Informasi yang terdapat difacebook selain tentang hiburan, juga berisi informasi terbaru berkaitan dengan komunitas, informasi ilmiah atau aplikatif yang disebarkan maupun informasi personal berkaitan dengan kehidupan seseorang (Caers, 2013).Penggunaan media sosial terutama facebook tidak selalu bersifat kesenangan semata, namun juga banyak keuntungan lain yang didapat misalnya dapat digunakan sebagai ajang pembelajaran dengan diskusi-diskusi ilmiah, area untuk berjualan online, dan sebagainya. Bahkan rata-rata siswa di Amerika Serikat yang memiliki prestasi akademik tinggi, mereka memanfaatkan facebook (Pesek dalam Cares, 2013). Hal ini menunjukkan bahwa perilaku penggunaan facebook dari masing-masing individu berbeda-beda, tergantung pada motif dan tujuannya.

\section{Penelitian Terkait}

Beberapa penelitian terdahulu yang berkaitan dengan perilaku informasi remaja dalam memanfaatkan media sosial yaitu sebagai berikut. Pertama penelitian yang dilakukan oleh Hamzah Nasutiaon (2016), dengan judul, "Perilaku Remaja Pengguna Media Sosial Blackberry Messenger, Line dan Whatsapp Dalam Perspektif Gender (Kasus Siswa SMA Negeri 3 Medan)". Penelitian tersebut mendeskripsikan perilaku remaja penggunaan media sosial dan menganalisis hubungan perilaku remaja pengguna media sosial dengan perspektif gender. Hasil penelitian menunjukan bahwa media sosial Line merupakan media sosial dengan intentitas yang paling tinggi dan kepentingan pengguna paling besar pada kategori informasi di antara media sosial Blackberry Messenger dan WhatsApp. Ini mengambarkan bahwa media sosial Line merupakan media sosial yang digemari oleh siswa-siswi SMA Negeri 3 Medan sehingga tingkat perilaku pada siswa-siswi tersebut juga tinggi.

Penelitian kedua dilakukan oleh Mulawarman dan Aldila Dyas Nurfitri (2017), dengan judul "Perilaku Pengguna Media Sosial beserta Implikasinya Ditinjau dari Perspektif Psikologi Sosial Terapan". Penelitian tersebutmendeskripsikan tentang hegemoni media sosial dari perspektif psikologi sosial terapan dengan harapan dapat memberi kontribusi terhadap upaya pengendalian perilaku penggunaan media sosial. Hasil penelitian menunjukkan bahwa Hegemoni media sosial meliputi konsep, teori dan hasil penelitian psikologi sosial dalam perilaku individu yang berhubungan dengan topik-topik terkait aktivitas penggunaan media sosial, seperti swafoto, cyberwar, belanja daring, personalisasi diri pengguna, dan budaya share.

Dari penelitian terdahulu yang sudah ada, terdapat perbedaan dan persamaan dengan penelitian yang akan dilakukan. Persamaanya yaitu sama-sama mengkaji tentang perilaku 
pengguan dalam memanfaatkan media sosial. Sedangkan perbedaan dengan penelitian Hamzah Nasution yaitu perilaku yang diteliti tidak hanya tertuju pada pengguna berdasarkan perspektif gender sedangkan penelitian ini berkaitan dengan perilaku informasi yang konteksnya lebih luas. Selain itu dari teori, subjek dan objek yang dikaji juga berbeda. Perbedaan dengan yang dilakukan Mulawarman dan Aldila yaitu terdapat pada perspektif yang dikaji, teori yang digunakan, subjek dan juga objek yang dikaji.

\section{METODE}

Metode Penelitian berisi jenis penelitian, informan, teknik pengumpulan data, dan teknik analisis data

Penelitian Perilaku Informasi Remaja dalam Memanfaatkan Facebook menggunakan pendekatan kualitatif deskriptif. Penelitian kualitatif deskriptif, adalah penelitian yang digunakan untuk mendapatkan pemahaman mendalam terhadap suatu isu/permasalahan dalam setting alamiahnya, dimana selama penelitian peneliti berfokus pada usaha menginterpretasikan perilaku informasi remaja dalam memanfaatkan facebook yang dilandasi kondisi psikologis, kognitif, dan demografis mereka. Penelitian ini menggunakan berbagai macam sumber data sehingga peniliti bisa mengembangkan gambaran komperhensif tentang permasalahan/isu yang diteliti (Cresswell, 2014). Sejalan dengan hal tersebut maka sasaran dalam penelitian ini bukanlah pengukuran, melainkan pemahaman dan analisis mendalam terhadap perilaku informasi remaja dalam memanfaatkan facebook dalam setting alamiahnya.

Data dari penelitian ini berupa keseluruhan perilaku informasi remaja dalam memanfaatkan facebook yang terdiri dari kebutuhan informasi, perilaku pencarian, evaluasi, dan pemanfaatan informasi. Sumber data berupa akun facebook dan pengguna facebook, dengan kriteria sebagai berikut.

(1) Rentang usia pengguna antara 18-24 tahun. Rentang usia tersebut dipilih berdasarkan kriteria usia remaja yang ditetapkan oleh Newman dengan karakteristik memiliki kemandirian berpikir, mampu mengambil keputusan untuk dirinya sendiri, dan merupakan salah satu kelompok pengguna media sosial terbesar (Newman; Caers, 2013).

(2) Mengetahui konsep perilaku informasi

(3) Berada di Malang

Adapun teknik pengumpulan data yang digunakan dalam penelitian ini adalah wawancara mendalam, observasi dan juga analisis dokumen. Berikut ini adalah prosedur pengumpulan data.

(1) Penelitian diawali dengan mewawancarai informan potensial terkait kebutuhan informasi yang mereka miliki, pendapat informan tentang informasi yang ada di facebook, dan pemahaman tentang bagaimana informasi tersebut dimanfaatkan

(2) Setelah wawancara maka selanjutnya adalah observasi. Observasi difokuskan pada perilaku informasi yang terdiri dari perilaku pencarian informasi dengan memanfaatkan facebook, mengevaluasi informasi yang didapatkan, dan bagaimana informasi tersebut dimanfaatkan

(3) Peneliti kemudian melakukan analisis dokumen menggunakan jurnal dan buku yang membahas tentang perilaku informasi dan media sosial, untuk mendapatkan teori yang mendukung dan menjelaskan hasil wawancara dan diskusi

Teknik analisis dilakukan dengan prosedur sebagai berikut.

(1) Koding

Data penelitian dari observasi, wawancara, dan analisis dokumen dikumpulkan kemudian dikelompokkan dan dikodekan berlandaskan konsep perilaku informasi dari TD Wilson. Kode pada penelitian ini dibagi menjadi empat kategori yaitu kebutuhan informasi, pencarian informasi, evaluasi informasi, dan pemanfaatan informasi.

(2) Triangulasi data

Data penelitian yang sudah dikodekan dalam empat kategori di atas (kebutuhan informasi, perilaku pencarian, evaluasi, dan pemanfaatan informasi) kemudian diperiksa dengan 
menggunakan berbagai sumber data yang berbeda (pengguna, akun facebook, buku, dan jurnal) untuk membangun justifikasi konsep yang diwakili dari masing-masing kode, jika ada data baru yang didapatkan dari proses triangulasi, maka data tersebut akan ditambahkan untuk meningkatkan validitas penelitian.

(3) Penyajian data

Setelah data ditriangulasi maka langkah selanjutnya adalah menyajikan deskripsi data dengan cara mendeskripsikan setting dan perspektif pengguna facebook yang dilandasi oleh konteks lingkungan, kognitif, dan demografis yang mempengaruhi perilaku informasi mereka. Narasi diikuti dengan kutipan wawancara yang menunjukkan hal tersebut.

\section{HASIL DAN PEMBAHASAN}

\section{Seseorang dalam Konteksnya}

Konteks kebutuhan informasi seseorang berkaitan dengan motivasi yang melatarbelakangi individu untuk memunculkan kebutuhan Informasi. Menurut Wilson dalam Potnis (2015), motivasi tersebut dibagi menjadi: a) unlearned motives, b) social motives, c) economics, d) physiological, e) affective, dan $\mathrm{f}$ ) cognitive. Berkaitan dengan motivasi yang dibutuhkan oleh individu terhadap kebutuhan informasi, sebagian besar informan menyatakan pada awal pencarian menggunakan facebook, mereka tidak memiliki motivasi khusus.

"Ngga ada si mba, cuma kalo iseng saja" (AB)

"Biasanya kalo pas bosen ya buka-buka aja" (AA)

"ngga si mba, kalo pas nganggur ngga ada kerjaan atau kalo lagi nunggu

lama ya cek facebook"(AD)

Dari kutipan wawancara di atas menunjukkan bahwa informan tidak memiliki motivasi tertentu yang memunculkan kebutuhan informasi saat mereka mengakses facebook. Mereka beranggapan saat mengakses facebook mereka tidak memiliki kebutuhan informasi apapun, karena perilaku mengakses facebook dinilai sebagai kegiatan spontan yang tidak didasari oleh motif apapun. Informan menganggap bahwa motivasi yang memunculkan kebutuhan informasi justru muncul saat mereka berinteraksi dengan news feed yang direkomendasikan oleh facebook. Berikut ini kutipan wawancara dengan informan:

"...kalo sudah liat foto-foto teman yang di beranda atau artikel yang direkomendasikan, nah dari situ baru saya seperti ada motivasi untuk tahu lebih banyak" (AA)

“...kepo aja kalo sudah baca-baca status atau liat foto teman, kayak eh mereka ngapain sih, lagi dimana, makanannya enak gitu-gitu”(AD)

Berdasarkan kutipan wawancara di atas menegaskan bahwa motivasi yang memunculkan kebutuhan informasi muncul bukan sebelum mereka berinteraksi dengan informasi, tetapi saat mereka sudah berinteraksi dengan informasi, tetapi setelah melakukan wawancara lebih jauh ditemukan bahwa sebelum mengakses facebook ditemukan fakta bahwa tindakan mereka sebenarnya didasari oleh motivasi yang dikategorikan sebagai social motives, dan unlearned motives..

Unlearned motives merupakan motivasi yang didasari oleh rasa ingin tahu sedangkan social motives merupakan motivasi yang didasari oleh kebutuhan berafiliasi, pengakuan, dan agresi(Willson dalam Al-Suqri \& Al -Aufi, 2015). Kedua motif tersebut tidak disadari oleh informan karena mereka menilai bahwa motif yang mempengaruhi informasi terbatas pada aspek peningkatan pengetahuan dan kompetensi, sehingga saat mereka mengakses facebook kesadaran akan adanya motivasi yang mendorong kebutuhan informasi rendah, disisi lain alogaritma informasi yang digunakan oleh facebook menyebabkan informasi pada news feed informan adalah informasi menarik dan relevan (Caers,dkk. 2015), yang memunculkan motivasi terhadap kebutuhan informasi secara signifikan, sehingga informan hanya mampu merasakan motivasi signifikan yang muncul setelah mereka mengakses informasi dan mengesampingkan motivasi sebelum mereka berinteraksi dengan informasi yang ada dalam facebook. 
Dominannya social motives dan Unlearned motives yang menjadi dasar informan memiliki kebutuhan informasi terjadi karena beberapa faktor, diantaranya informan yang menjadi sumber informasi dalam penelitian ini rata-rata berusia remaja, keinginan untuk menjadi bagian dari kelompok tergolong tinggi (Andriadi, 2016), sehingga tidak mengherankan jika social motives menjadi salah satu motif yang dominan. Media sosial seperti facebook memiliki pengaruh signifikan terhadap interaksi sosial terutama pada remaja. Social Networking Site, bukan hanya terbatas pada melakukan hal lama dengan cara yang baru, tetapi lebih jauh lagi SNS menimbulkan perubahan pada interaksi sosial, remaja saat ini selalu ingin terhubung dengan kelompok sosialnya, hal tersebut menyebabkan mereka membutuhkan informasi berkaitan dengan kelompoknya yang kemudian mereka gunakan untuk mendesain identitas mereka dalam media sosial untuk dapat bersosialisasi. Social motives selanjutnya berpengaaruh pada unlearned motives. Keinginan untuk menjadi bagian yang diakui oleh suatu kelompok seperti yang dijelaskan di atas menyebabkan remaja mempunyai rasa ingin tahu yang tinggi tentang informasi yang berkaitan dengan kelompok sosialnya. Mereka ingin mempelajari hal-hal baru yang berkaitan dengan kelompok mereka agar selalu bisa terhubung dengan kelompok, unlearned motives juga merupakan bentuk kepedulian para informan terhadap kelompok sosial dimana mereka menjadi bagiannya.

Jadi, motivasi yang memunculkan kebutuhan informasi awalnya tidak disadari oleh remaja, tetapi kemudian ditemukan bahwa kebutuhan informasi mereka dilandasi atas social motives dan unlearned motives hal tersebut terjadi karena remaja memiliki keinginan bersosialisasi yang tinggi, social motives dan unlearned motives mempengaruhi jenis kebutuhan informasi remaja. Berdasarkan analisis feedback pada 70 akun informan ditemukan 6 topik utama informasi yang mereka dapatkan dari facebook dan mencerminkan social motives dan unlearned motives:

Kategori Topik yang Social motives dan Unlearned motives

\begin{tabular}{|c|l|l|}
\hline No & \multicolumn{1}{|c|}{ Topik } & \multicolumn{1}{|c|}{ Definisi } \\
\hline 1. & Kabar orang-orang terdekat & $\begin{array}{l}\text { Berkaitan dengan kabar keluarga, teman, dan rekan } \\
\text { kerja yang berhubungan dengan status hubungan, } \\
\text { tempat tinggal, kesibukan, dan event terbaru }\end{array}$ \\
\hline 2. & Hiburan & $\begin{array}{l}\text { Berkaitan dengan video, meme, tempat tongkrongan } \\
\text { favorit,gosip yang populer di lingkaran sosial } \\
\text { informan, dan kuis-kuis lucu yang ada di facebook }\end{array}$ \\
\hline 3. & Hobi & $\begin{array}{l}\text { Fashion, kecantikan, resep masakan, olahraga, travelling, } \\
\text { dan game online }\end{array}$ \\
\hline 4. & Pelajaran hidup dan kata-kata mutiara \\
\hline 5. & Isu Politik & $\begin{array}{l}\text { Pelajaran tentang hidup dan kata-kata mutiara yang } \\
\text { berkaitan dengan cinta, impian, dan perjuangan hidup } \\
\text { tokoh-tokoh terkenal }\end{array}$ \\
\hline 6. & Pendidikan dan pekerjaan & $\begin{array}{l}\text { Berita tentang presiden atau mentri, kasus korupsi, } \\
\text { kebijakan atau undang-undang terbaru, dan kinerja } \\
\text { pemerintahan }\end{array}$ \\
\hline
\end{tabular}

\section{Mekanisme Pengaktifan}

Setelah diketahui motivasi yang mempengaruhi munculnya kebutuhan informasi, maka langkah selanjutnya adalah menganalisis mekanisme pengaktifan. Mekanisme pengaktifan dalam model perilaku informasi Willson muncul dua kali. Mekanisme pengaktifan pertama, muncul setelah konteks kebutuhan informasi, yang berusaha menjelaskan proses bagaimana kebutuhan informasi berubah/ tidak berubah menjadi perilaku informasi menggunakan teori stress. Menurut Willson, kekurangan informasi menyebabkan ketidakpastian yang bisa memunculkan stres. Saat level stres yang disebabkan oleh kurangnya informasi mencapai ambang batas, stres tersebut akan merubah kebutuhan informasi menjadi perilaku informasi. Selanjutnya stres juga dipengaruhi oleh karakteristik sumber informasi, tipe dan usaha pencarian. 
Mekanisme pengaktifan kedua, muncul setelah variabel intervensi yang mencakup teori tentang resiko dan imbalan serta motivasi untuk mencapai kesuksesan. Teori tantang resiko dan imbalan pada teori Willson berkaitan dengan resiko apa saja yang diambil saat seseorang memutuskan untuk melakukan pencarian informasi serta imbalan apa saja yang akan didapatkannya dari lingkungan sekitar serta dari dalam diri sendiri (motivasi untuk sukses) (Willson dalam Al-Suqri \& Al-Saufi, 2015).

Motivasi yang melandasi kebutuhan informasi informan, menyebabkan informan memiliki kebutuhan informasi yang berupa kebutuhan informasi sosial dan rasa ingin tahu, selanjutnya bagaimana kebutuhan informasi tersebut berubah/tidak berubah menjadi perilaku akan dijelaskan pada point ini. Pada mekanisme pengaktifan yang pertama, peneliti menggunakan teori stres yang dikaitkan dengan karakteristik sumber informasi dan usaha pencarian menggunakan sumber tersebut. Berdasarkan hasil wawancara ditemukan bahwa sebagian besar informan memilih untuk merubah kebutuhan informasinya menjadi perilaku pencarian informasi menggunakan facebook. Berikut ini kutipan wawancara yamg menunjukkan hal tersebut:

"ya gimana mba, soalnya kontennya menarik jadi enggak tahu kenapa harus cek

facebook terus, enggak bisa berhenti" (BB)

"soalnya keaya hiburan dan refreshing" (AB)

"karena kalau aku udah kepo, ya harus di cari tahu dan yang ada di facebook itu

bikin kepo terus (AA)

"kalau tidak aku cari, nanti ketinggalan gosip dengan teman-teman" (BC)

Kutipan wawancara di atas menunjukkan bahwa faktor utama yang merubah kebutuhan informasi menjadi perilaku informasi dikarenkan mereka merasa tidak bisa menanggulangi stres yang berupa perasaan tidak terhubung dengan kelompok sosialnya dan tidak mendapatkan hiburan. Kedua faktor tersebut menunjukkan betapa pentingnya perasaan terhubung dan terhibur bagi para informan.

Pada tahun 2013, facebook dan IDC berkolaborasi dalam sebuah penelitian tentang penggunaan facebook, dari penelitian tersebut ditemukan bahwa hadirnya media sosial menyebabkan keinginan untuk selalu terhubung dan terhibur kapan saja, dimana saja, dengan berbagai latar budaya berbeda menjadi lebih kuat dari sebelumnya (Facebook \& IDC, 2013). Intensifnya pemasaran sosial media yang selalu menekankan betapa pentingnya terhubung dan terhibur, merubah persepsi masyarkat. Sebelumnya, masyarakat tidak berpikir bahwa selalu terhubung dan terhibur secara online adalah suatu keharusan, tetapi terjadi perubahan yang signifikan khususnya pada kalangan remaja. Remaja saat ini mempunyai ketergantungan yang tinggi terhadap media sosial, saat mereka tidak bisa mengakses media sosial seperti facebook mereka mengalami anxiety (Andriadi, 2016).

Anxiety yang dirasakan oleh remaja terbentuk dari rasa kesepian, bosan, perasaan tidak menjadi bagian dari suatu kelompok, dan tidak disadarinya eksistensi individu oleh orang-orang sekitar saat mereka tidak memenuhi kebutuhan informasi mereka melalui sosial media. Remaja yang menjadi informan dalam penelitian ini juga mengungkapkan hal yang sama. Mereka menganggap bahwa facebook merupakan wadah dan representasi diri mereka sebagai individu yang unik, representasi virtual ini harus selalu terhubung dengan representasi virtual anggota kelompok lainnya yang dipenuhi melalui pencarian informasi, sehingga saat mereka tidak melakukan pencarian informasi informan menganggap mereka tidak terhubung, hal tersebut akan menimbulkan masalah bukan hanya di dunia maya, tetapi juga berdampak pada dunia nyata.

Permasalahan yang muncul diantaranya adalah tidak dilibatkannya mereka dalam diskusi dengan kelompok sosial, dijauhi dan tidak mengenali anggota kelompok, tidak dianggap menjadi bagian dari kelompok, kesepian, dan merasa tidak dianggap. Permasalahan di atas, secara tidak sadar mendorong informan untuk melakukan pencarian informasi secara intensif. Berdasarkan hasil observasi dan wawancara, ditemukan bahwa dalam satu hari informan mengakses facebook minimal enam kali dengan durasi rata-rata 45 menit untuk setiap kali akses. 
Faktor yang mendorong perubahan kebutuhan informasi menjadi perilaku informasi selanjutnya adalah karakteristik sumber informasi. Kemajuan teknologi, informasi disebarluaskan kepada masyarakat melalui beragam saluran. Masyarakat bisa mengakses informasi tidak hanya melalui sumber informasi tercetak atau sumber informasi elektronik saja, tetapi juga sumber informasi via internet. Berdasarkan penelitian yang dilakukan oleh Sun-Kim ditemukan bahwa sebagian besar remaja cenderung memanfaatkan sumber informasi yang memanfaatkan internet untuk memenuhi kebutuhan informasi, terutama sosial media yang isinya merupakan kontribusi dari end user, seperti facebook (Sun Kim, dkk. 2011).

Pendapat Sun-Kim sejalan dengan pendapat informan. Seluruh informan menyatakan bahwa mereka menganggap facebook sebagai sumber informasi yang bermanfaat, karena menurut informan melalui facebook mereka mendapatkan informasi dari sumber yang dapat dipercaya. Karakteristik facebook sebagai sumber informasi yang pemanfaatan utamanya digunakan untuk berbagi informasi personal yang berkaitan dengan kegiatan sehari-hari dan informasinya bersifat ringan (Caers, 2013), ternyata merupakan faktor pendorong penting bagi informan untuk merubah kebutuhan informasi mereka menjadi perilaku informasi.

Mayoritas informan menyadari bahwa banyak berita hoax yang beredar di facebook, tetapi mereka tetap mempunyai perspektif positif dalam melihat facebook sebagai sebuah sumber informasi. Perspektif positif terhadap facebook sebagai sumber informasi disebabkan karena informasi yang disediakan oleh facebook mudah untuk didapatkan dan merupakan sumber informasi yang relevan dengan kebutuhan pengguna. Informan menyatakan tanpa perlu melakukan pencarian aktif seperti pada sumber informasi lain, mereka bisa mendapatkan informasi yang ramai diperbincangkan dalam kelompok sosial mereka, dan informasi tersebut dinilai sebagai modal sosial yang efektif untuk menghubungkan informan dengan lingkungan sosial mereka.

Mekanisme pengaktifan yang kedua, berkaitan dengan resiko dan imbalan serta motivasi dari dalam diri individu yang menyebabkan mereka melakukan perilaku informasi. Informan dalam penelitian ini menyatakan bahwa walaupun ada beberapa kendala yang mereka hadapi (dijelaskan pada variabel intervening), resiko yang mereka hadapi saat tidak memenuhi kebutuhan informasi memaksa informan untuk melakukan pencarian informasi.

Resiko yang mempunyai peran signifikan menurut para informan adalah eksistensi dan pengakuan dari kelompok sosialnya. Kedua faktor tersebut menumbuhkan motivasi dalam diri informan untuk selalu mencari dan memanfaatkan informasi yang mereka dapatkan pada facebook. Saat informasi tersebut terpenuhi, informan merasa mereka lebih siap untuk berinteraksi dengan lingkungan sosial.

Menurut informan lingkungan sosial mempunyai peran penting dalam kehidupan mereka, disini informan mengaitkan lingkungan sosial dengan konsep seperti identitas, eksistensi, pengakuan, perhatian, keterhubungan, dan citra yang mempunyai hubungan erat dengan pemanfaatan informasi pada media sosial.

Resiko yang dinyatakan oleh informan saat mereka tidak merubah kebutuhan informasi menjadi pencarian, mereka merasa bahwa kelompok sosialnya tidak tahu tentang dirinya (identitas), merasa tidak mempunyai citra yang membuat kelompok sosial mengakui keberadaan informan, tidak adanya perhatian dari kelompok sosial menimbulkan perasaan kesepian dan keterasingan yang berdampak nyata pada kehidupan mereka. Kondisi demikian, bagi remaja yang pada dasarnya belum memiliki kestabilan emosi, yang melihat kelompok sosial dan pergaulan merupakan hal yang penting (caers, dkk., 2013) menimbulkan motivasi dari dalam diri mereka untuk selalu bisa memenuhi kebutuhan tersebut.

Jadi, mekanisme pengaktifan yang merubah kebutuhan informasi menjadi perilaku informasi menggunakan facebook di dorong karena keinginan informan untuk selalu terhubung dengan kelompok sosialnya dan karakteristik facebook sebagai sumber informasi membantu informan untuk mengatasi dorongan tersebut melalui penerapan konsep end user yang menyebabkan informasi dalam facebook merupakan informasi yang bermanfaat untuk dijadikan 
modal sosial bagi informan untuk berinteraksi dengan lingkungan sosial dan sekitar mereka. Resiko yang muncul apabila kebutuhan informasi tidak dipenuhi memotivasi informan untuk selalu memenuhi kebutuhan informasi mereka.

\section{Variabel Intervensi}

Variabel intervensi merupakan hambatan dan faktor pendorong yang dihadapi dalam memenuhi kebutuhan informasi. Variabel ini terdiri dari faktor demografis, peran individu dalam lingkungan sosial, dan lingkungan. Faktor demografis berkaitan dengan umur, jenis kelamin, latar belakang pendidikan, pekerjaan, dan penghasilan. Peran individu dalam lingkungan sosial berkaitan dengan posisi seorang individu dalam kelompok sosialnya, dan lingkungan berkaitan dengan lingkungan geografis dan lingkungan sosial yang mendorong atau menghambat seorang individu dalam memenuhi kebutuhan informasi.

\section{Demografis}

Informan dalam penelitian ini berjumlah 70 orang informan yang terdiri dari 35 laki-laki dan 35 perempuan, berlatar belakang pendidikan S1 Ilmu perpustakaan (50 informan) dan D3 Perpustakaan (20 informan), dan berusia 18-24 tahun.

Kondisi demografis yang berperan signifikan dalam perilaku informasi berkaitan dengan usia dan jenis kelamin. Berdasarkan hasil wawancara dan observasi, menunjukkan bahwa faktor umur berpengaruh pada intensitas pemenuhan kebutuhan informasi informan. Semakin muda informan, maka semakin sering informan tersebut mengakses facebook untuk memenuhi kebutuhan informasinya, dan sebaliknya.

Kaitan antara usia dengan intensitas perilaku informasi menggunakan facebook, dipengaruhi oleh self worth, keinginan untuk bersama, dan promosi diri. Informan dengan usia lebih muda menunjukkan bahwa keinginan untuk dilihat berharga, keinginan untuk menjadi bagian dari kelompok, dan mempromosikan diri lebih tinggi dibanding dengan informan dengan usia lebih tua. Keinginan tersebut mendorong mereka untuk melakukan pencarian dan mempresentasikan diri melalui facebook.

"sering, soalnya kan temen-temen masih baru kenal, jadi sering kepo-kepo facebook mereka" (BB)

"tiap hari lah, soalnya suka gosip sama teman teman"(AD)

" beberapa kali sehari, soalnya suka kompakan komen di foto anak-anak"(AA)

Sementara, informan dengan usia yang lebih tua menunjukkan bahwa tiga hal tersebut kurang penting bagi mereka, walaupun perilaku informasi yang ditunjukkan masih dipengaruhi oleh keinginan untuk dilihat berharga, keinginan untuk menjadi bagian dari kelompok, dan mempromosikan diri lebih tinggi dibanding dengan informan dengan usia lebih tua, tetapi intensitas yang ditunjukkan berkurang.

Selain faktor usia, jenis kelamin juga mempengaruhi perilaku informasi dengan memanfaatkan facebook. Ditemukan bahwa informan dengan jenis kelamin perempuan memiliki motivasi lebih tinggi untuk memenuhi kebutuhan informasi mereka dibandingkan dengan informan laki-laki.

Informan berjenis kelamin perempuan menyatakan bahwa mereka lebih sering mencari informasi di facebook karena setiap hari mereka akan berdiskusi dengan kelompok sosialnya tentang orang-orang yang mereka kenal. Tuntutan untuk menunjukkan diri sebagai anggota kelompok sosial tertentu secara konsisten lebih dirasakan oleh perempuan daripada laki-laki. Sementara untuk informan laki-laki menyatakan sebaliknya, mereka memerlukan informasi tentang kelompoknya, tetapi jika mereka mengetahui terlalu banyak anggota kelompok sosialnyaa menganggap bahwa hal tersebut terlalu berlebihan, sehingga intensitas pencarian dan penggunaan informasi dari facebook frekuensinya tidak sebanyak perempuan.

"ya kan perempuan, seneng gosip jadi harus sering-sering kepo" (AD)

"kalo laki-laki tau kebanyakan, nanti dianggap kaya cewvek, tukang gosip" (BB) 
Jadi, faktor demografi yang berpengaruh signifikan pada informan adalah usia dan jenis kelamin. Semakin muda usia informan intensitas pencarian dan penggunaan informasi semakin tinggi, dan sebaliknya. Perempuan memiliki motivasi lebih kuat untuk melakukan perilaku informasi daripada laki-laki.

\section{Peran Individu dan Lingkungan}

Point ini akan membahas tentang peran individu dengan individu lainnya serta bagaimana lingkungan sosial individu tersebut mempengaruhi perilaku informasi. Peran individu di dalam lingkungan sosial secara sederhana, dibagi menjadi dua, yaitu yang memimpin dan yang dipimpin. Individu yang "memimpin" merupakan individu yang dianggap memiliki peran sosial penting, ia merupakan tempat bertanya bagi anggota-angota kelompok sosial karena dianggap memiliki pengetahuan yang lebih (Lampe, Cliff dkk., 2012).

Pada informan menunjukkan pola yang sama, informan yang dianggap memiliki peran penting dalam lingkungan sosialnya (seperti dianggap paling gaul atau paling pintar) menunjukkan perilaku informasi yang lebih aktif daripada mereka yang tidak. Mereka menganggap memiliki kewajiban untuk memiliki lebih banyak pengetahuan dan untuk bisa menjawab pertanyaan temanteman, sehingga mereka bisa mengembangkan kualitas kelompok sosialnya.

" setiap hari mba, karena rasanya gimana gitu kalau ngga tahu, terus temen-temen nanya” (AC)

"kalau OOTD tiap hari, soalnya kalau fashion itu gantinya cepet, jadi harus update terus $(B D)$

Untuk informan yang berperan bukan sebagai individu yang memimpin kelompok sosial, perilaku informasi mereka lebih pasif. Mereka menganggap lebih baik menunggu informasi dari pemimpin kelompok sosial mereka, karena mereka beranggapan informasi dari ketua kelompok sosial dinilai lebih benar dan relevan. Jadi, individu yang mempunyai peran sebagai pemimpin anggota kelompok menunjukkan perilaku informasi lebih aktif daripada mereka yang tidak.

\section{Perilaku Pencarian Informasi}

Perilaku pencarian informasi merupakan perilaku yang ditunjukkan oleh eorang individu saat mereka berinteraksi dengan informasi (willson dalam Al-Suqri \& Al-Aufi 2015). Sebagian besar informan menunjukkan perilaku pencarian pasif, hanya sedikit yang menunjukkan adanya perilaku pencarian informasi aktif dan berkelanjutan.

Kecenderungan informan melakukan pencarian informasi pasif disebabkan karena mereka kurang menyadari kebutuhan informasi yang dimiliki, karena menganggap kebutuhan akan hiburan dan rasa penasaran bukan merupakan bagian dari kebutuhan informasi, sehingga saat mengakses facebook mereka tidak bersikap aktif, hanya menikmati saja informasi yang mereka dapatkan dari facebook.

"dilihat-lihat saja, biasanya penasarannya setelah baca informasinya" (AA)

"Dari facebook banyak si informasinya tapi tipenya facebook kita tidak bisa mencari informasi"

Faktor lain yang menyebabkan sebagian besar informan menunjukkan perilaku pencarian pasif adalah karena karakteristik fitur facebook yang menyediakan informasi untuk user berdasarkan pola pencarian, keterbaruan, dan isu terhangat dalam kelompok sosial user tersebut, dan membatasi kata kunci pencarian. User hanya bisa mencari informasi berdasarkan nama pengguna, sehingga pencarian informasi pasif menjadi pilihan sebagian besar informan.

Pencarian informasi aktif ditemukan pada informan yang dianggap sebagai "pemimpin" pada kelompok sosialnya, mereka memilih untuk mencari secara aktif dengan cara menanyakan informasi yang mereka butuhkan melalui chat dengan pengguna yang lain, bukan hanya mengkonsumsi informasi yang disediakan oleh facebook.

Para informan yang menunjukkan perilaku pencarian informasi aktif cenderung memanfaatkan facebook sebagai tempat diskusi dengan komunitas atau individu yang informan nilai memiliki keahlian yang melebihi informan. Mereka menunjukkan perilaku mengabaikan feeds 
yang tidak menunjang keahlian. Pola pencarian seperti ini kemudian berubah menjadi pencarian berlanjut.

Perubahan pencarian aktif menjadi pencarian berlanjut pada informan yang dianggap sebagai "pemimpin" kelompok sosialnya terjadi karena mereka ingin terus mengembangkan keahlian yang dimiliki, sehingga mereka merasa memerlukan informasi terbaru mengenai keahlian mereka secara terus-menerus. Selain itu, pencarian informasi berkelanjutan tidak hanya terjadi pada informan yang dianggap sebagai "pemimpin" kelompok sosial, tetapi terjadi juga pada anggota kelompok sosial lainnya. Informan yang kedudukan sosialnya sebagai individu yang "dipimpin" juga menunjukkan pola perilaku pencarian berlanjut untuk informasi tertentu. Seperti informasi yang berkaitan dengan hobi atau orang terdekat informan tersebut.

\section{Penggunaan Informasi}

Perilaku pencarian dan pengumpulan informasi tidak selalu menjadi perilaku penggunaan informasi, karena adanya faktor kognitif dari individu pengguna informasi. Tidak semua informasi yang dikumpulkan oleh pengguna bisa dimanfaatkan, kemampuan menganalisis kemudian mengaplikasikan informasi tergantung pada kemampuan kognitif individu (Al-Suqri \& Al-Aufi).

Berdasarkan hasil wawancara dan observasi sebagian besar informasi yang didapatkan dari facebook tidak bisa diaplikasikan untuk memenuhi kebutuhan informasi. Bukan hanya faktor kognitif yang dimiliki oleh informan, tetapi juga karena karakteristik informasi yang dibagikan oleh facebook.

Informan menganggap facebook bermanfaat dan informasi yang dibagikan relevan dengan kebutuhan informasi yang mereka miliki, tetapi disisi lain informan menyatakan bahwa sebagian besar informasi yang mereka dapatkan hanya menarik perhatian dan rasa ingin tahu saja, sehingga mereka hanya membaca informasi tersebut tetapi tidak digunakan. Berikut petikan wawancara yang menunjukkan hal tersebut:

"kalau ada informasi terbaru atau yang penting dan bermanfaat saya bagikan, tetapi biasanya informasdi facebook itu untuk dibaca-baca saja" (AB)

"kalau informasi ringan biasanya digunakan sebagai bahan obrolan dengan temanteman, tetapi kalau informasinya bagus saya bagikan di media sosial lain" (CC)

"kalau informasinya dari sumber yang bisa dipercaya dan cocok dengan saya biasanya saya bagikan ke teman-teman yang mungkin membutuhkan informasi tersebut, tetapi kalo informasi dari facebook biasanya untuk lucu-lucuan si ya"(AE)

Dari kutipan wawancara di atas kita bisa mengetahui bahwa user melakukan analisis terlebih dahulu terhadap informasi yang mereka dapatkan melalui facebook. Analisis yang dilakukan bertujuan untuk mengevaluasi kualitas informasi yang mereka dapatkan. Analisis tersebut meliputi analisis sumber, keterbaruan informasi, dan konten informasi itu sendiri.

Informasi yang oleh informan dinilai berkualitas akan dibagikan kepada kelompok sosialnya, melalui komunikasi verbal dan juga melalui media sosial lainnya. Dorongan menggunakan informasi yang berkualitas menurut informan disebabkan karena mereka tidak ingin kredibilitas mereka menurun di dalam kelompok sosial.

"malu mba kalau membagi informasi ternyata informasi yang dibagikan itu Hoax"

(AA)

"aku pernah kan ya ngeshare informasi dari facebook, eh ternyata informasinya

Cuma boongan terus diketawain sama teman-teman"

Jadi, kemampuan kognitif seseorang tidak hanya berpengaruh pada intensitas orang tersebut memanfaatkan informasi, tetapi lebih berpengaruh pada kualitas informasi yang mereka dapatkan. Informan, sebelum mereka memanfaatkan informasi, mereka terlebih dulu menganalisis kualitas informasi yang akan mereka gunakan.

\section{PENUTUP}

\section{Simpulan}


Berdasarkan hasil penelitian, dapat diambil kesimpulan sebagai berikut:

Penelitian perilaku informasi remaja dalam memanfaatkan media sosial facebook, diawali dari analisis kebutuhan informasi samapai pemanfaatan informasi. Pada analisis kebutuhan informasi ditemukan bahwa motivasi utama informan yang menyebabkan munculnya kebutuhan informasi adalah motivasi sosial dan rasa ingin tahu terhadap hal baru. Motivasi tersebut berubah menjadi kebutuhan informasi yang berkaitan dengan informasi tentang lingkungan sosial dan juga hiburan. Faktor pendorong utama yang menyebabkan informan merubah kebutuhan informasinya menjadi perilaku informasi adalah karena informan membutuhkan informasi dari media sosial untuk menunjukkan identitas diri, membangun citra, terhubung, dan menjadi bagian dari suatu kelompok. Saat kebutuhan informasi tersebut tidak dipenuhi remaja merasakan anxiety yang dikarenakan perasaan kesepian, merasa tidak dianggap keberadaannya, dan tersisihkan dari lingkungan sosial

Pencarian informasi menunjukkan pencarian informasi pasif, hal tersebut dikarenakan karakteristik dari facebook yang menerapkan konsep web 3.0 dimana alogaritma facebook akan menganalisis pola pencarian informasi pengguna, informasi yang diperbincangkan oleh kelompok sosial pengguna, dan informasi terbaru dalam lingkungan sosial mereka, selain itu karakteristik lain berupa terbatasnya kata kunci yang bisa digunakan untuk pencarian informasi. di dalam facebook pencarian informasi hanya bisa dilakukan dengan cara mencari nama pengguna, faktorfaktor tersebut menyebabkan pencarian informasi sebagian besar informan menunjukkan perilaku pencarian pasif.

Perilaku pemanfaatan informasi pada informan menunjukkan bahwa sebagian besar informasi yang mereka dapatkan tidak digunakan, faktor penyebabnya dikarenakan informan melakukan aktifitas kognitif berupa menganalisis informasi yang didapatkannya dari segi author informasi, konten informasi, serta keterbaruan. Mereka menghindari menggunakan informasi yang kurang berkualitas karena khawatir terhadap pendapat anggota lain dalam kelompok sosial. Informasi yang didapatkan dari facebook akan digunakan apabila informasi tersebut dinilai bermanfaat, terutama bila informasi tersebut bermanfaat bagi anggota kelompok sosial. Mereka akan menggunakan informasi tersebut dalam diskusi atau membagikan informasi kepada anggota kelompok melalui media sosial lainnya

\section{Saran}

.Perilaku informasi remaja menggunakan facebook berkaitan erat dengan keinginan remaja untuk menjadi bagian dari suatu lingkungan sosial, sehingga informasi yang mereka dapatkan berkaitan erat dengan informasi yang membuat remaja bisa diterima dilingkungan sosial, remaja menggunakan informasi tersebut sebagai modal sosial mereka, tetapi ternyata informasi yang mereka dapatkan dari perilaku informasi mereka dinilai kurang memberi keuntungan pada perkembangan diri individu, melihat hal tersebut peneliti menyarankan bahwa informasi yang mereka dapatkan dari media sosial dikembangkan pemanfaatannya, bukan hanya sekedar sarana untuk terlihat keren tetapi digunakan sebagai sarana untuk membangun jaringan sosial yang kuat. Pembangunan jaringan sosial bisa dilakukan jika informan merubah perilaku pasif mereka menjadi perilaku pencarian aktif dengan cara menghubungi melalu facebook chat anggota di dalam lingkungan sosial atau di luar lingkungan sosial mereka yang dinilai mempunyai keahlian tertentu. Jadi tidak hanya menikmati feeds dalam beranda mereka, tetapi aktif berdiskusi tentang berbagai macam topik dengan pengguna facebook yang dinilai ahli.

Pada nantinya diskusi tersebut tidak hanya akan memberikan keuntungan berupa informasi yang bersifat hiburan saja, tetapi informasi dari chat dari pengguna facebook yang dinilai "ahli" dapat digunakan untuk memperluas jaringan dan menambah pengetahuan yang bisa meningkatkan kualitas diri individu.

\section{DAFTAR PUSTAKA}


Almas, H., Andajani, K., \& Istiqomah, Z. (2018). Hubungan Kebutuhan Informasi Mahasiswa Program Studi Ilmu Perpustakaan dalam Penyelesaian Skripsi dengan Ketersediaan Koleksi. BIBLIOTIKA : Jurnal Kajian Perpustakaan dan Informasi, 2(1), 63-71.

Andriadi, F. (2016). Demokrasi di tangan netizen. Jakarta: RMBooks

APJII. (2016). Infogrfis: Penetrasi dan Perilaku Pengguna Internet Indonesia. Aspsiasi Penyelenggara Jasa Internet Indonesia. Diakses dari https://apjii.or.id/downfile/file/surveipenetrasiinternet2016.pdf

APJII. (2016). Saatnya Jadi Pokok Perhatian Pemerintah dan Industri. Buletin APJII, ed. 05November.

Diakses dari https://apjii.or.id/downfile/file/BULETINAPJIIEDISI05November2016.pdf

Behaviour \& Information Technology. (2010). Behaviour \& Information Technology, 29(6). doi:10.1080/0144929x.2010.527096

Caers, R., et.al.(2013). Facebook: A Literature. New Media \& Society 15 (6) 982-1002. Sage Publication. Diakses dari http://www.psych.utoronto.ca/users/tafarodi/psy427/articles/Caers $\% 20 \mathrm{et} \% 20 \mathrm{al} . \% 20(2$ $\underline{013) \cdot \mathrm{pdf}}$

Facebook \& IDC. (2013). Always Conected. Diakses dari https://www.nu.nl

Graham, W. (2012). Introducing the Facebook Platform. Beginning Facebook Game Apps Development, 171-200. doi:10.1007/978-1-4302-4171-3_8

Hamzah, N. (2016). Perilaku Remaja Pengguna Media Sosial Blackberry Messenger, Line dan Whatsapp dalam Perspektif Gender. Skripsi. Bogor: Fakultas Ekologi Manusia, Institut Pertanian Bandung. Diakses dari http://repository.ipb.ac.id/jspui/bitstream/123456789/81934/1/I16hna.pdf

Hermina, P. (2010). Aplikasi Facebook Paling Top. Yogyakarta: Andi

Information Needs, Information Sources and Information Use. (2005). Information Development,21(2), 91-92. doi:10.1177/0266666905054500

Kellner, D. (2009). Budaya media, jurnal studies, identitas dan politik: antara modern dan postmodern. Jalasutra.

Knight, S. A., \& Spink, A. (2008). Toward a Web Search Information Behavior Model. Web Search Information Science and Knowledge Management, 209-234. doi:10.1007/978-3540-75829-7_12

Laws of the Information Age. (2010). Putts Law \& the Successful Technocrat, 117-120. doi:10.1002/9780471788942.ch22

Mideast Youth: Can Social Media = Social Change? (n.d.). Media, Spiritualities and Social Change. doi:10.5040/9781472549112.ch-00

Mulawarman \& Aldila Dyas Nurfitri. (2017). Perilaku Pengguna Media Sosial Beserta Implikasinya Ditinjau dari Perspektif Psikologi Terapan. Buletin Psikologi, Vol. 25, No. 1, 36-44. Diakses dari https://jurnal.ugm.ac.id/buletinpsikologi

Nahrowi, M. I. (2017). IMPLEMENTASI PERKEMBANGAN SISTEM INFORMASI MENGGUNAKAN LIMA TAHAP SKENARIO EVOLUSI DI PERPUSTAKAAN SMK NEGERI 4 MALANG. BIBLIOTIKA : Jurnal Kajian Perpustakaan Dan Informasi, 1(1), 71-80. https://doi.org/10.17977/um008v1i12017p071

Noor, M. U. (2018). Penilaian kualitas informasi sebagai bentuk sikap tabayyun ketika menerima informasi di sosial media dan internet. BIBLIOTIKA : Jurnal Kajian Perpustakaan dan Informasi, 2(1), 33-40.

Pendit, P. L. (2008). Perilaku Informasi, Semesta Pengetahuan. Diakses dari http://www.pustakaindonesia.org/wp-content/uploads/2012/05/Perilaku-InformasiSemesta-Pengetahuan.pdf

Saputra, A. (2010). Analisis Pengaruh Kepuasan Kualitas dan Experiential Marketing Terhadap Word of Mouth Situs Jejaring Sosial Facebook Pada Mahasiswa Fakultas Ekonomi Undip. Skripsi: Universitas Dipenogoro. Diakses dari http://eprints.undip.ac.id/26418/ 
The Future of Social Media. (2016). Strategic Social Media, 326-341. doi:10.1002/9781119370680.ch20

Treadaway, Chris \& Mari Smith. 2010. Facebook Marketing: An Hour a Day. Canada: Wiley Publishing.

Vaish, A., Demir, Ö E., \& Baldwin, D. (2011). Thirteen- and 18-month-old Infants Recognize When They Need Referential Information. Social Development, 20(3), 431-449. doi:10.1111/j.1467-9507.2010.00601x

Wilson, T.D. (1999). Model in Information Behaviour Research. 1999. Journal of Documentation, vol 55 no. 33, hal. $259 \quad$ - $270 . \quad$ Diakses dari http://www2.hawaii.edu/ donnab/lis610/TDWilson Only 1999.pdf

Wilson, T.D. (2000). Recent trends in user studies: action research and qualitative methods. Information Research, Vol. 5 No. 3, April 2000. Diakses dari http://bogliolo.eci.ufmg.br/downloads/WILSON\%20Information\%20Research.pdf

Yusuf, M. P. \& Priyo S. (2010). Teori dan Praktik Penelusuran Informasi: Information Retrieval. Jakarta: Kencana 